\title{
Evaluation of the Pharmaceutical Quality of Some Quinine Preparations Sold in Nigeria
}

\author{
Jolly A. Nnamdi ${ }^{\text {Ikhuoria M. Arhewoh }}{ }^{\text {b }}$ Augustine O. Okhamafe ${ }^{b}$ \\ Ehijie F.O. Enato ${ }^{c}$ \\ a Pharmacy Department, Delta State Hospital Management Board, Asaba, ${ }^{b}$ Departments of Pharmaceutics \\ and Pharmaceutical Technology and ${ }^{\mathrm{C} C}$ linical Pharmacy and Pharmacy Practice, Faculty of Pharmacy, \\ University of Benin, Benin City, Nigeria
}

\section{Key Words}

Oral liquids $\cdot$ Parenteral administration $\cdot$ Pharmaceutical quality $\cdot$ Quinine preparations $\cdot$ Tablets

\begin{abstract}
Objective: The purpose of this study was to determine the pharmaceutical quality of quinine preparations sold in Nigerian markets. Materials and Methods: The organoleptic and physicochemical properties of quinine tablets, as well as oral liquids and parenteral quinine preparations, were assessed according to British Pharmacopoeia (BP) and unofficial standards as recommended by the manufacturers. Results: Of the 6 brands of tablets assessed, 4 passed the uniformity of content test and 5 the disintegration test, but only 2 the dissolution test. The $\mathrm{pH}$ of 2 of the 6 brands of oral liquid preparations met BP standards, while only 1 oral liquid met the BP standard for percentage content. The assay further demonstrated that 4 brands of the parenteral preparations met BP standards for quinine content. All the parenteral preparations were found to be sterile. Conclusion: Quinine preparations sold in Nigeria varied considerably in their pharmaceutical quality. A strict check of the quality of brands of quinine by regulatory agencies and distributors before they are sold to the public is therefore recommended.
\end{abstract}

Copyright @ 2009 S. Karger AG, Basel
(C) 2009 S. Karger AG, Basel

1011-7571/09/0183-0193\$26.00/0

Fax +4161306 1234

E-Mail karger@karger.ch

www.karger.com
Accessible online at:

www.karger.com/mpp

\section{Introduction}

Malaria is a tropical parasitic disease caused by the protozoa plasmodia. Four species are responsible for human malaria: $P$. falciparum, $P$. ovale, $P$. vivax and $P$. malariae. Of these, $P$ falciparum is the most dangerous and accounts for the vast majority of malaria deaths, particularly in tropical Africa [1]. Globally, 300-500 million clinical cases of malaria occur annually, out of which more than 1 million people die of the disease $[2,3]$. Children below 5 years of age and pregnant women are most affected [3,4]. Malaria is a leading cause of low birth weight among infants, and contributes to a high rate of maternal death $[4,5]$.

Early diagnosis with prompt and effective treatment is one of the strategies for anti-malarial intervention in endemic countries. However, drug resistance may decrease the efficacy of the anti-malarial drug therapy [1]. The World Health Organization (WHO) in 1999 and 2001 developed and recommended artemisinin-based combination therapy in the management of acute uncomplicated P. falciparum malaria [6]. Most African countries south of the Sahara have adopted this policy. Despite this, the traditional anti-malarial drug 'quinine' still has a place in anti-malarial chemotherapy. For example, according to the National Anti-Malarial Poli- 
Table 1. Label information on quinine preparations evaluated

\begin{tabular}{|c|c|c|c|c|c|c|c|}
\hline $\begin{array}{l}\text { Type of } \\
\text { formulation }\end{array}$ & $\begin{array}{l}\text { Brand } \\
\text { codes }\end{array}$ & Manufacturer & $\begin{array}{l}\text { Batch } \\
\text { number }\end{array}$ & $\begin{array}{l}\text { Date of } \\
\text { manufacture }\end{array}$ & $\begin{array}{l}\text { Expiry } \\
\text { Date }\end{array}$ & $\begin{array}{l}\text { Labeled } \\
\text { strength }\end{array}$ & $\begin{array}{l}\text { NAFDAC } \\
\text { number }\end{array}$ \\
\hline \multirow[t]{4}{*}{ Tablet } & $\mathrm{T}_{\mathrm{A}}$ & Subvick, UK & 8205 & $3 / 2005$ & $3 / 2008$ & $300 \mathrm{mg}$ & yes \\
\hline & $\mathrm{T}_{\mathrm{C}}$ & Alpha, India & TE 215 & $4 / 2005$ & $3 / 2008$ & $300 \mathrm{mg}$ & yes \\
\hline & $\mathrm{T}_{\mathrm{D}}$ & NEM lab, India & TQ-1 & $12 / 2005$ & $11 / 2007$ & $300 \mathrm{mg}$ & no \\
\hline & $\mathrm{T}_{\mathrm{E}}$ & PharmEthicals, India & T4-065 & $10 / 2004$ & $10 / 2007$ & $300 \mathrm{mg}$ & yes \\
\hline \multirow[t]{6}{*}{ Liquid } & $\mathrm{L}_{\mathrm{A}}$ & Service, Nigeria & BN 0L & $12 / 2005$ & $12 / 2007$ & $50 \mathrm{mg} / 5 \mathrm{ml}$ & no \\
\hline & $\mathrm{L}_{\mathrm{B}}$ & Merit, India & OM-001 & $1 / 2005$ & 2/2009 & $100 \mathrm{mg} / 5 \mathrm{ml}$ & no \\
\hline & $\mathrm{L}_{\mathrm{C}}$ & Campharm, Nigeria & $10-512$ & $10 / 2005$ & $10 / 2008$ & $100 \mathrm{mg} / 5 \mathrm{ml}$ & yes \\
\hline & $\mathrm{L}_{\mathrm{D}}$ & Nomagbon, Nigeria & NP-03 & $6 / 2006$ & $5 / 2008$ & $150 \mathrm{mg} / 5 \mathrm{ml}$ & yes \\
\hline & $\mathrm{L}_{\mathrm{E}}$ & Moko, Nigeria & 3489 & $11 / 2005$ & $10 / 2008$ & $100 \mathrm{mg} / 5 \mathrm{ml}$ & yes \\
\hline & $\mathrm{L}_{\mathrm{F}}$ & Herfaust links, Nigeria & - & $8 / 2005$ & $12 / 2008$ & $50 \mathrm{mg} / 5 \mathrm{ml}$ & no \\
\hline \multirow{3}{*}{ Parenteral } & $\mathrm{P}_{\mathrm{D}}$ & Maxheal, India & NMH502 & $4 / 2005$ & $3 / 2008$ & $600 \mathrm{mg} / 2 \mathrm{ml}$ & yes \\
\hline & $\mathrm{P}_{\mathrm{E}}$ & Laborate, India & 4QA 18 & $11 / 2004$ & $10 / 2007$ & $600 \mathrm{mg} / 2 \mathrm{ml}$ & yes \\
\hline & $\mathrm{P}_{\mathrm{F}}$ & Medreich, India & G4024 & $10 / 2004$ & $10 / 2007$ & $600 \mathrm{mg} / 2 \mathrm{ml}$ & yes \\
\hline
\end{tabular}

cy of Nigeria, parenteral quinine is indicated in the management of severe malaria, while oral quinine is recommended in the management of acute uncomplicated malaria in pregnancy [7]. In Nigeria, quinine is inexpensive and readily available despite the significant adverse effects associated with its use, such as cinchonism and tinnitus. In order to ensure that available quinine preparations in circulation meet pharmaceutical standards in terms of quality, it may be necessary to conduct pharmaceutical evaluations of both oral and parenteral quinine preparations. Therefore, the objective of this study was to evaluate the pharmaceutical qualities of quinine products obtained in the Nigerian market.

\section{Materials and Methods}

\section{Drug Sampling}

On a cross-sectional basis, quinine tablets and parenteral and oral liquid preparations ( 6 brands each) were purchased between February and June 2006 from pharmacies and shops in Onitsha, the neighbouring town of Asaba, as well as from Benin City and Warri, all in Southern Nigeria. The study locations were chosen because it has been reported that drug counterfeiting occurs mostly in open markets, one of which is located in Onitsha [8]. No particular sampling procedure was employed. One of the researchers, posing as a 'normal' customer, purchased the drugs without prescription from drug shops. The different brands and formulations were obtained from drug stores wherever they could be found, until 6 samples of each dosage form were collected. Following purchase, information on manufacturer's address and country of origin of the brand, batch number, manufacturing date, expiration dates, labeled strength, and registration status by the National Agency of Food and Drug Administration and Control (NAFDAC) were recorded from the product label where available (table 1).

\section{Drug Analyses}

The analyses of the various dosage forms and brands were carried out within the month of July 2006. Quinine powder, which was used as standard, was obtained from Service Pharmaceuticals, Benin City, Nigeria. All other chemicals used for the analyses were of analytical grade. Preliminary examination of the organoleptic properties was carried out for all the drug samples collected. The following properties were evaluated for tablets: colour, taste, inscription on surface (if any), finishing (dull or glossy), coating type (if any) and odour. For the organoleptic properties, 3 assessors took part in the evaluation, including J.A.N. and I.M.A. Each assessor evaluated all the products, and differences in observations were handled objectively. The decision of a majority (at least 2) was taken. The apriori definitions for evaluation were based on the relativity of our findings to the descriptions of the physicochemical properties listed in British Pharmacopoeia (BP) 2003 for dosage forms of quinine. 
Table 2. Results of organoleptic and physicochemical properties of quinine tablets

\begin{tabular}{llllllrrr}
\hline $\begin{array}{l}\text { Brand } \\
\text { code }\end{array}$ & Colour & Coating type & Taste & $\begin{array}{l}\text { Inscription } \\
\text { (if any) }\end{array}$ & Finishing/odour & $\begin{array}{l}\text { Mean weight } \\
\pm \mathrm{SD}, \mathrm{mg}\end{array}$ & $\begin{array}{l}\text { Actual } \\
\text { content, \% }\end{array}$ & $\begin{array}{l}\text { Disintegration } \\
\text { time } \pm \mathrm{SD}, \mathrm{min}\end{array}$ \\
\hline $\mathrm{T}_{\mathrm{A}}$ & white & sugar coated & sweet & Qs 300 & glossy/odourless & $0.745 \pm 0.193$ & 90.1 & $18 \pm 0.2$ \\
$\mathrm{~T}_{\mathrm{B}}$ & white & uncoated & bitter & - & smooth/odourless & $0.436 \pm 0.023$ & 4.3 & $3 \pm 0.1$ \\
$\mathrm{~T}_{\mathrm{C}}$ & white & sugar coated & sweet & C. Qd & glossy/odourless & $0.631 \pm 0.028$ & 95.7 & $18 \pm 0.3$ \\
$\mathrm{~T}_{\mathrm{D}}$ & white & sugar coated & sweet & Quinine & glossy/odourless & $0.762 \pm 0.042$ & 100.5 & $>120$ \\
$\mathrm{~T}_{\mathrm{E}}$ & white & sugar coated & sweet & T. Quinine 300 & glossy/odourless & $0.766 \pm 0.030$ & 97.5 & $9 \pm 0.2$ \\
$\mathrm{~T}_{\mathrm{F}}$ & white & sugar coated & sweet & T. Quinine 300 & glossy/odourless & $0.676 \pm 0.023$ & 96.6 & $11 \pm 0.3$ \\
\hline
\end{tabular}

\section{Analyses of Tablets}

The tablets were assessed for uniformity of weight and content (20 tablets each), disintegration time and dissolution rate according to BP 2003. The disintegrations of 6 tablets per brand were determined in distilled water at $37 \pm 0.5^{\circ} \mathrm{C}$ using Manesty Tablet Disintegration Apparatus, while the dissolution rate was carried out using Manesty Dissolution Test Apparatus (Manesty Machines, Liverpool, England). This was fitted with a basket rotated at $100 \mathrm{rpm}$ using $900 \mathrm{ml}$ of $0.1 \mathrm{M}$ hydrochloric acid as dissolution medium, maintained at $37 \pm 0.5^{\circ} \mathrm{C}$. One tablet at a time from each brand was placed in the basket, and lowered into the vessel containing the dissolution medium. A $10 \mathrm{ml}$ sample was withdrawn at time interval of $5 \mathrm{~min}$ from the middle of the beaker and replaced with the dissolution medium. The sample was filtered and diluted with an equal volume of $0.1 \mathrm{M} \mathrm{HCl}$. This was continued for $40 \mathrm{~min}$. The absorbance of the solution was measured at wavelength of $348 \mathrm{~nm}$ [9]. The test was carried out in triplicate and the mean was calculated.

\section{Analyses of Liquid Preparations}

Both parenteral and oral preparations were assessed for clarity, $\mathrm{pH}$, specific gravity and viscosity, while only the parenteral preparations were assayed for content uniformity and sterility according to BP 2003 [9].

\section{Assay of Oral Liquid Quinine}

The BP 2003 method for assaying quinine dihydrochloride injection was used with some modifications. Briefly, a volume containing $0.3 \mathrm{~g}$ of quinine salt was diluted to $20 \mathrm{ml}$ with distilled water and $5 \mathrm{ml}$ of $5 \mathrm{M}$ sodium hydroxide was added to precipitate the alkaloid. Extraction was carried out with successive quantities of $10 \mathrm{ml}$ of chloroform until complete extraction of the drug was effected, the chloroform layer was washed with water and separated from the aqueous layer with the aid of a separating funnel, and dried using a hot air oven. The residue was dissolved with 50 $\mathrm{ml}$ of anhydrous glacial acetic acid to which $20 \mathrm{ml}$ of acetic anhydride and $5 \mathrm{ml}$ mercuric acetate was added (where the hydrochloride salt was present). Crystal violet solution was included as an indicator, and $0.1 \mathrm{M}$ perchloric acid was titrated against the mixture. The end point was taken. The percentage of quinine present was calculated from the formulae: each millilitre of $0.1 \mathrm{M}$ perchloric acid is equivalent to $0.01804 \mathrm{~g}$ of quinine hydrochloride, while each millilitre of $0.1 \mathrm{M}$ perchloric acid is equivalent to $0.249 \mathrm{~g}$ of quinine sulphate.

Pharmaceutical Quality of Quinine Preparations

\section{Results}

The correlation coefficient $\left(\mathrm{r}^{2}\right)$ of the standard quinine curve and the assay sensitivity were 0.997 and $>95 \%$, respectively.

The samples of quinine preparation were either manufactured locally or imported from other countries. For example, all the tablets and parenteral preparations were imported, while some of the oral liquid preparations were made in Nigeria. They were all within a reasonable shelf life at the time of sampling and analyses (table 1).

\section{Quinine Tablets}

Pre-analysis of tablets revealed that of the 6 brands examined, 5 were sugar coated and 1 was uncoated (table 2). Furthermore, all the coated tablets were smooth and glossy with an unbroken inscription on the tablet surface. They were evenly coloured and whitish. Coatings are included to protect quinine from photo degradation, mask the very bitter taste as well as to add aesthetic appeal to the product. The results of the organoleptic and physicochemical properties are shown in table 2 . The dissolution tests for 4 brands of tablets are shown in figure 1 . The dissolution tests for $T_{B}$ and $T_{D}$ were not included because $\mathrm{T}_{\mathrm{D}}$ did not disintegrate after $120 \mathrm{~min}$ and $\mathrm{T}_{\mathrm{B}}$ had $4.3 \%$ active content. Only $\mathrm{T}_{\mathrm{A}}$ and $\mathrm{T}_{\mathrm{E}}$ released over $70 \%$ of their quinine content after $40 \mathrm{~min}$.

One brand of the liquid quinine had India as the country of origin on the label, while the other 5 brands were manufactured locally. Three of the 6 brands of the liquid preparations were not registered by NAFDAC (table 1 ). Brand $\mathrm{L}_{\mathrm{E}}$ was observed to be greenish yellow in colour, while $L_{B}$ and $L_{F}$ were colourless. The results for $\mathrm{pH}$ and percentage of quinine content also revealed marked variation from BP requirements (table 3).

All the parenteral preparations were imported and had NAFDAC registration numbers. The results of or- 
Table 3. Results of organoleptic and physicochemical properties of oral liquid quinine

\begin{tabular}{|c|c|c|c|c|c|c|c|c|}
\hline $\begin{array}{l}\text { Brand } \\
\text { code }\end{array}$ & Odour & Taste & Primary package & $\begin{array}{l}\text { Colour/visual } \\
\text { clarity }\end{array}$ & $\mathrm{pH}$ & $\begin{array}{l}\text { Specific } \\
\text { gravity }\end{array}$ & $\begin{array}{l}\text { Kinematic vis- } \\
\text { cosity, } \mathrm{mm}^{2} / \mathrm{s}\end{array}$ & $\begin{array}{l}\text { Actual } \\
\text { content, \% }\end{array}$ \\
\hline $\mathrm{L}_{\mathrm{A}}$ & odourless & bitter & amber-coloured glass bottle & amber yellow & 2.2 & 0.99 & 1.15 & 90.2 \\
\hline $\mathrm{L}_{\mathrm{B}}$ & aromatic smell & bitter & amber-coloured plastic bottle & colourless & 2.0 & 0.98 & 1.15 & 32.5 \\
\hline $\mathrm{L}_{\mathrm{C}}$ & aromatic smell & bitter & amber-coloured plastic bottle & amber yellow & 3.4 & 0.99 & 1.16 & 140.7 \\
\hline $\mathrm{L}_{\mathrm{D}}$ & odourless & bitter & amber-coloured glass bottle & amber yellow & 3.3 & 0.98 & 1.16 & 97.0 \\
\hline $\mathrm{L}_{\mathrm{E}}$ & odourless & bitter & amber-coloured plastic bottle & greenish yellow & 6.3 & 0.99 & 1.16 & 138.3 \\
\hline $\mathrm{L}_{\mathrm{F}}$ & odourless & faintly bitter & amber-coloured glass bottle & colourless & 5.5 & 0.98 & 1.18 & 28.3 \\
\hline
\end{tabular}

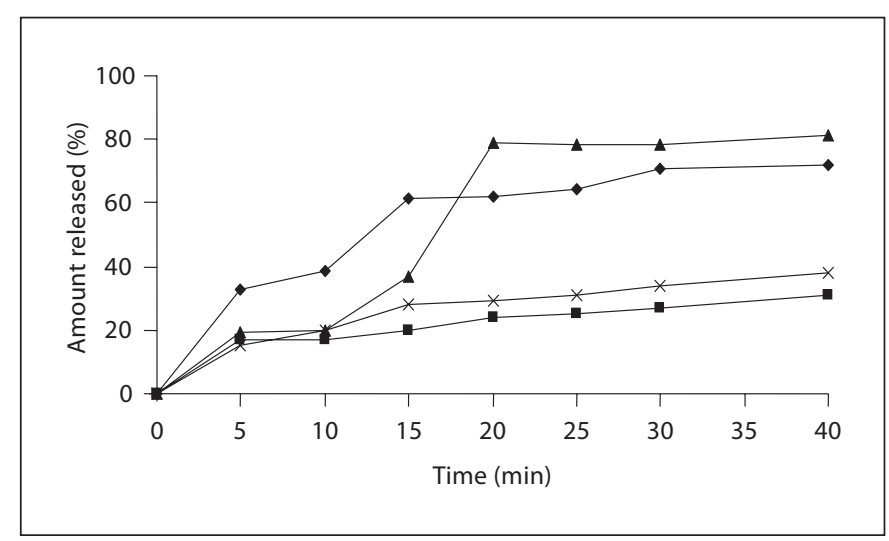

Fig. 1. Dissolution of quinine tablets in $0.1 \mathrm{M} \mathrm{HCl}$ release medium. $\boldsymbol{\nabla}=\mathrm{T}_{\mathrm{A}} ; \boldsymbol{\square}=\mathrm{T}_{\mathrm{C}} ; \boldsymbol{\Delta}=\mathrm{T}_{\mathrm{E}} ; \times=\mathrm{T}_{\mathrm{F}}$.

ganoleptic properties revealed that there was uniformity and compliance in taste, colour, odour, visual clarity and primary packaging with the $\mathrm{BP}$ requirement. The physicochemical properties also demonstrated that the $\mathrm{pH}$, specific gravity and contents were uniform, except for brands $\mathrm{P}_{\mathrm{D}}$ and $\mathrm{P}_{\mathrm{F}}$, which were higher than the required 95-105\% specified by the BP 2003 (table 4).

\section{Discussion}

\section{Quinine Tablets}

Physicochemical properties are important in solid dosage forms, for example, disintegration. The BP 2003 stipulates a disintegration time of no less than $15 \mathrm{~min}$ for uncoated tablets and $30 \mathrm{~min}$ for coated tablets and capsules. The result showed that 5 of the 6 brands, i.e., $T_{A}$, $\mathrm{T}_{\mathrm{B}}, \mathrm{T}_{\mathrm{C}}, \mathrm{T}_{\mathrm{E}}$ and $\mathrm{T}_{\mathrm{F}}$, conformed to the $\mathrm{BP}$ requirement, while brand $\mathrm{T}_{\mathrm{D}}$ did not disintegrate after $120 \mathrm{~min}$. The conformity of the other brands of tablets to the BP specification for disintegration can be explained to be due to
Table 4. Results of some physicochemical properties of parenteral quinine preparations

\begin{tabular}{llll}
\hline Brand codes & $\mathrm{pH}$ & Specific gravity & Actual content, \% \\
\hline $\mathrm{P}_{\mathrm{A}}$ & 3.17 & 0.96 & 108.5 \\
$\mathrm{P}_{\mathrm{B}}$ & 3.91 & 0.9 & 105 \\
$\mathrm{P}_{\mathrm{C}}$ & 3.44 & 1.09 & 99.9 \\
$\mathrm{P}_{\mathrm{D}}$ & 3.44 & 1.06 & 111.3 \\
$\mathrm{P}_{\mathrm{E}}$ & 3.2 & 1.05 & 105 \\
$\mathrm{P}_{\mathrm{F}}$ & 3.24 & 1.08 & 133 \\
\hline
\end{tabular}

the appropriate use of disintegrant and other excipients like binders and lubricants by the manufacturers. On the other hand, the non-disintegration of $\mathrm{T}_{\mathrm{D}}$ could have been due to either excessive use of binders or inadequate use of disintegrant, hence the tablet core, being strongly held together, prevented penetration of disintegration fluid into the tablet. Another possible factor is poor storage, for example, storage under high relative humidity or high temperature that interfered with the properties of the disintegrant and binders. It has also been reported that excessive use of lubricants by the manufacturer can prevent the penetration of disintegration fluid, since most lubricants are hydrophobic [10]. The type of disintegrant used and the method of incorporation of the disintegrant could also affect the rapid release of the drug into solution. Four of the 6 brands of tablets complied with the BP requirement for the uniformity of content. The reason for non-compliance of brand $\mathrm{T}_{\mathrm{A}}$ could be due to poor in-process control during manufacture, as well as inaccurate weighing and mixing during preparation. In brand $\mathrm{T}_{B}$, the quinine content was abysmally low; this appears to be deliberate as the drug was not even registered by the regulatory authority and there is no proper manufacturer's address on the label. This further reveals the steady presence of unregistered products. 
Dissolution studies give an idea of the amount of drug available for absorption after oral administration. Drugs with a poor dissolution profile will not be available in the body's systems or target organs/tissues to elicit a therapeutic effect. The BP 2003 states that $70 \%$ of the tablet drug should dissolve within $40 \mathrm{~min}$. Brands $\mathrm{T}_{\mathrm{A}}$ and $\mathrm{T}_{\mathrm{E}}$ passed, while $T_{C}$ and $T_{F}$ failed the dissolution test, and hence a sufficient amount of the drug would not be available for absorption to elicit the expected therapeutic effect when administered. Besides the fact that dissolution studies were not carried out for $T_{B}$ and $T_{D}$, they also did not have NAFDAC registration number, suggesting that they may have been smuggled into the country.

\section{Oral Liquid Quinine Preparations}

The result of the oral liquid preparation revealed a high level of disparity among the different brands and a reasonably high deviation from the $\mathrm{BP}$ requirements for oral liquid preparations (table 3 ). $\mathrm{L}_{C}$ and $\mathrm{L}_{\mathrm{E}}$ were stored in plastic containers which could release alkalis into the solution. This is noticeable in $\mathrm{L}_{\mathrm{E}}$, in which the liquid quinine $\mathrm{HCl}$ preparation had turned greenish, obviously due to alkaline release from the plastic container or as a result of contamination of the product by microbes. Furthermore, brands $\mathrm{L}_{\mathrm{B}}$ and $\mathrm{L}_{\mathrm{F}}$ were observed to be colourless. $\mathrm{L}_{\mathrm{F}}$ had a $\mathrm{pH}$ of 5.5 and its taste was not bitter; this was considered to be due to the low quinine content of the preparation. Moreover, neither of these 2 brands were registered by the regulatory authority (NAFDAC). The results of the $\mathrm{pH}$ of the preparation indicate that only brands $\mathrm{L}_{\mathrm{A}}$ and $\mathrm{L}_{\mathrm{B}}$ were within the acceptable $\mathrm{pH}$ range of 1.5-3.0 for quinine hydrochloride. There appears to be poor compliance with good laboratory and manufacturing processes by the manufacturers of some of these products, such as $\mathrm{L}_{\mathrm{A}}, \mathrm{L}_{\mathrm{C}}$ and $\mathrm{L}_{\mathrm{E}}$. $\mathrm{L}_{\mathrm{B}}$ and $\mathrm{L}_{\mathrm{F}}$ may be counterfeit products as very low concentrations of quinine were measured. This may explain the reason for the colourless appearance of these preparations.

\section{Parenteral Quinine Preparations}

All the parenteral preparations except $\mathrm{P}_{\mathrm{F}}$ appeared safe (since it had more than $20 \%$ excess of the labeled claim). This may have resulted from inaccurate weighing by the manufacturer and non-adherence to standard operating procedures on weighing. Another possible reason is overage by the manufacturers; however, such practice is not encouraged as this may lead to overdose and quinine toxicity when administered to patients. The sterility test for the injections demonstrated no growth of fungi or bacteria in the injections, suggesting that they were sterile. This may indicate a high degree of hygiene on the part of the manufacturers, and strict adherence to sterile production techniques.

For all dosage form types of quinine (tablet, oral liquid and parenteral), a strict check of the quality of products by regulatory agencies and distributors before they are sold to the public is therefore recommended.

\section{Conclusion}

This study showed that there are still some problems with the pharmaceutical quality of quinine products available in the Nigerian market. A number of the tablets and liquid preparations fell below the regulatory standards, irrespective of whether the product was manufactured locally or imported. A strict check of the quality of brands of quinine by regulatory agencies and distributors before they are sold to the public is therefore recommended.

\section{References}

1 World Health Organization: Expert Committee on Malaria (WHO Technical Report Series 892, 12th Report). Geneva, WHO, 2000, pp 3-6.

2 Sachs J, Malaney P: The economic and social burden of malaria. Nature 2002;415:680685.

3 World Health Organization (WHO/AFRO): A Strategic Framework for Malaria Prevention and Control during Pregnancy in the African Region (AFR/MAL/04.01). Brazzaville, World Health Organization Regional Office for Africa, 2004.

4 Enato EFO, Okhamafe AO, Okpere EE, Oseji FI: Prevalence of malaria during pregnan- cy and antimalarial intervention in an urban secondary school health care facility in southern Nigeria. Med Princ Pract 2007;16: 240-243. DOI: $10.1159 / 000100399$.

5 Steketee RW, Wirima JJ, Slutsker L, Heymann DL, Breman JG: The problem of malaria control in pregnancy in sub-Saharan Africa. Am J Trop Med Hyg 1996;55(sup$\mathrm{pl}): 2-7$.

6 World Health Organization: Antimalarial Drug Combination Therapy: Report of the World Health Organization Technical Consultation. WHO, Geneva, 2001.

7 Federal Ministry of Health: National Malaria Control Policy for Nigeria. Lagos, Nation- al Malaria and Vector Control Division, $\mathrm{Ni}$ geria, 2004.

8 Ofonaike JO, Enato EFO, Okhamafe AO: A study of pharmaceutical quality of chloroquine and paracetamol products sold in a major Nigerian 'market'. Afr J Health Sci 2007;14:164-170.

9 British Pharmacopoeia Commission Secretariat: British Pharmacopoeia. London, Pharmaceutical Press, 2003.

10 Velasco MV, Munoz-Ruiz A, Monedero MC, Jimnez-Castellanos MR: Study of flowability of powders: effect of the addition of lubricants. Drug Dev and Ind Pharm 1995;21: 2385-2391. 